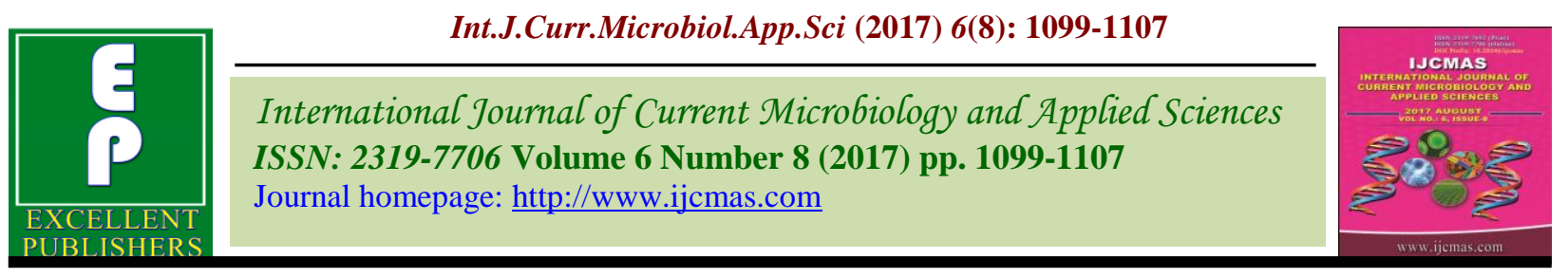

Original Research Article $\quad$ https://doi.org/10.20546/ijcmas.2017.608.136

\title{
Genetic Divergence Studies in Cluster Bean [Cyamopsis tetragonoloba (L.) Taub]
}

\author{
Praveen Choyal $^{1 *}$, Vijay Bahadur ${ }^{1}$, Radhelal Dewangan $^{1}, \operatorname{Ramesh}^{1}$, \\ Shatis Xaxa ${ }^{1}$ and Mithlesh Gupta ${ }^{2}$ \\ ${ }^{1}$ Department of Horticulture, ${ }^{2}$ Department of Biological Science, Sam Higginbottom University \\ of Agriculture, Technology and Sciences, Allahabad (U.P), India \\ *Corresponding author
}

\section{A B S T R A C T}

Keywords

Cluster bean,

Genetic divergence,

Mahalanobis D2,

Clusters distance.

Article Info

Accepted:

14 June 2017

Available Online:

10 August 2017
This study was carried out to assess the genetic divergence among 15 cluster bean genotypes using mahalanobis $\mathrm{D}^{2}$. Fifteen genotypes were grouped into four clusters. Maximum (6) genotypes were included in cluster II and minimum (1) in clusters IV. The maximum inter-cluster distance was observed between cluster II and cluster III (13811.78) followed by cluster II and cluster IV (8357.305) and cluster III and cluster IV (2561.462) showed minimum inter cluster distance. The percent contribution towards genetic diversity was maximum in pod yield per plant (g) contributed to $45 \%$ followed by pods/ plant $(22.00 \%)$. On the basis of inter- cluster distances and per se performances observed, the genotypes with specific characters can be utilized for hybridization programme.

\section{Introduction}

Cluster bean or guar bean is botanically called as [Cyamopsis tetragonoloba (L.) Taub.] belongs to family Leguminosae is an annual legume vegetable crop. It is a self pollinated crop with diploid chromosome number $2 \mathrm{n}=$ 14. It is also known as gawaar in Hindi and Marathi, Goruchikkudu kaya or Gokarakaya in Telugu, Gorikayie in Kannada and Kotthavarai in Tamil reported by (Vahrehvah.com, 2012). Guar is one of the most important and potential vegetable cum industrial crop grown for its tender pods for vegetable purpose and for endospermic gum [30-35\%]. Tender pods are nutritionally rich in energy (16Kcal), moisture $(81 \mathrm{~g})$, protein
$(3.2 \mathrm{~g})$, fat $(1.4 \mathrm{~g})$, carbohydrate $(10.8 \mathrm{~g})$, Vitamin A (65.3IU), Vitamin C (49 mg), calcium $(57 \mathrm{mg}$ ) and iron $(4.5 \mathrm{mg})$ for every $100 \mathrm{~g}$ of edible portion (Kumar and Singh, 2002). Seeds of cluster bean have a large endosperm when compared to other legumes, and contains galactomannan type of gum, which forms a viscous gel and has diversified industrial applications viz., paper, food, cosmetics, mining, petroleum, well drilling, pharmaceuticals etc (Pathak et al., 2009).

Genetic diversity is an important factor and also a pre-requisite in any hybridization programme. The available genetic diversity is 
essential for any crop improvement programme. The inclusion of diverse parents in hybridization programme serves the purpose of producing desirable recombinants. Multivariate analysis by means of Mahalanobi's $D^{2}$ statistic is a powerful tool in quantifying the degree of divergence at genotypic level. The grouping of genotypes based on $\mathrm{D}^{2}$ analysis will be useful in choosing suitable parental lines for heterosis breeding. In order to enhance the productivity, information on the nature and magnitude of genetic diversity present in the genotypes is a pre-requisite. The $\mathrm{D}^{2}$ statistics is found to be an effective tool among the various techniques available for genetic differentiation among population (Rao, 1952).

\section{Materials and Methods}

The experiment was carried out at the Horticulture Research Farm, Department of Horticulture, Naini Agricultural Institute, Sam Higginbottom University of Agriculture, Technology and Sciences Allahabad. The experimental material (15 genotypes) of cluster bean was collected from different sources given information below in (Table 1).

Fifteen genotypes of cluster bean was grown in a randomized block design with three replicates during Kharif season keep line to line distance of $45 \mathrm{~cm}$ and plant to plant distance of $30 \mathrm{~cm}$. The sowing of experimental material was done on 12/07/2016 during the year 2016-2017. Each plot size was $1.8 \mathrm{~m} \times 2 \mathrm{~m}$. Five competitive plants were selected at randomly tagged from each plot to record observation on various characters viz., plant height 45 and 90 days (cm), No. of branches 45 and 90 days, Days to $1^{\text {st }}$ flowering, Days to 50 per cent flowering, Days to $1^{\text {st }}$ pod picking, Pod length (cm), Pod width $(\mathrm{cm})$, Ten fresh pod weight (g), Number of clusters per plant, Number of pods per cluster, No. of pods per plant, pod yield per plant $(\mathrm{g})$, pod yield per hectare $(\mathrm{q})$, Ten dry pod weight (g), No of seed per pod, Hundred seed weight (g), Seed yield per plant (g), Seed yield/ha.(q).

\section{Results and Discussion}

The multivariate analysis $\left(\mathrm{D}^{2}\right)$ is a powerful tool to measure the genetic divergence within a set of genotypes. The analysis of variance showed that significant difference among the genotypes for all 20 characters studied (Fig. 3 ). This suggested the presence of appreciable amount of diversity among the genotypes under study. The computed $\mathrm{D}^{2}$ values for 15 genotypes had wide range showing high divergence among the genotypes. Based on relative magnitude of genetic distances, 15 genotypes were grouped into 4 clusters using Tocher's method (Table 2 and Fig. 1). Out of 4 clusters, cluster II was the largest comprising 6 genotypes followed by cluster I consisting 5 genotypes, cluster III with 4 genotypes and Cluster IV 1 genotypes, respectively. Cluster IV however, was solitary in regard to multivariate composition as it included only one genotype which was extraordinary for one or more characters. Thus, formation of cluster with different genotypes indicates diversity among genotypes. The grouping of genotypes into different constellation did not follow any specific pattern and was found independent of their geographic region.

The intra cluster distance ranged from (0) to (2457.37). The maximum intra-cluster distance was found in cluster IV (2457.37) followed by cluster I (1206.47), cluster III (1049.48). The clusters II was monogenotypic and recorded the least value (0) (Table 3). The maximum inter-cluster distance of (13811.78) was observed among the II and III cluster indicating large genetic difference among genotypes of these two cluster followed by 
cluster II and cluster IV (8357.305), cluster I and cluster III (5676.066), cluster I and cluster II (3562.381), cluster I and cluster IV (2823.086), minimum inter cluster distance of (2561.462) was observed between III and IV cluster indicating significantly lesser genetic difference among the genotypes of these two cluster. Maximum inter-cluster distance is indicative that genotypes falling in these clusters had wide diversity and can be used for hybridization programme to get better recombinants in the segregating generations. Low level of intra-cluster distance was indicative of narrow genetic variation within the cluster (Table 3 and Fig. 2).

The maximum cluster mean values for plant height at 45 days was recorded in cluster III $(53.29 \mathrm{~cm})$ and the minimum cluster mean values was recorded in cluster II $(28.00 \mathrm{~cm})$ with general mean $(43.06 \mathrm{~cm})$. The maximum cluster mean values for plant height at 90 days was recorded in cluster III $(115.21 \mathrm{~cm})$ and the minimum cluster mean values was recorded in cluster IV $(84.23 \mathrm{~cm})$ with general mean $(100.48 \mathrm{~cm})$. The maximum cluster mean values for number of branches 45 days was recorded in cluster II (7.66) and the minimum cluster mean values was recorded in cluster III (3.08) with general mean (4.91). The maximum cluster mean values for number of branches 90 days was recorded in cluster II (14.80) and the minimum cluster mean values was recorded in cluster III (6.55) with general mean (9.70). These results are similar with the finding of Girish et al., (2012). The maximum cluster mean values for days to first flowering was recorded in cluster III (37.93 days) and the minimum cluster mean values for was recorded in cluster I (33.95days) with general mean (35.51 days). The maximum cluster mean values for days to $50 \%$ flowering was recorded in cluster III (40.53days) and the minimum cluster mean values was recorded in cluster II (36.00 days) with general mean
(37.88 days). These results are similar with the finding of Rai et al., (2013). The maximum clusters mean values for days to $1^{\text {st }}$ pod picking was recorded in cluster IV (53.16days) and the minimum cluster mean values was recorded in cluster I (49.95 days) with general mean(51.17days). These results are similar with the finding of Girish et al., (2012). The maximum cluster mean values for pod width was recorded in cluster II $(0.94 \mathrm{~cm})$ and the minimum cluster mean values was recorded in cluster I IV $(0.76 \mathrm{~cm})$ with general mean $(0.83 \mathrm{~cm})$. The maximum cluster mean values for pod length was recorded in cluster III $(14.48 \mathrm{~cm})$ and the minimum cluster mean values was recorded in cluster IV $(7.12 \mathrm{~cm})$ with general mean $(10.86 \mathrm{~cm})$. These results are similar with the finding of Rai et al., (2013). The maximum cluster mean values for 10 Fresh pod weight (g) was recorded in cluster III $(25.20 \mathrm{~g})$ and the minimum cluster mean values was recorded in cluster IV (10.30 g) with general mean $(18.17 \mathrm{~g})$. The maximum cluster mean values for number of clusters per plant was recorded in cluster IV (68.96) and the minimum cluster mean values was recorded in cluster II (36.00) with general mean (54.85). The maximum cluster mean values for number of pods/cluster was recorded in cluster IV (9.63) and the minimum cluster mean values was recorded in cluster II (7.00) with general mean (8.73). These results are similar with the finding of Muthuselvi et al., (2013) and Rai et al., (2013). The maximum cluster mean values for number of pods/plant was recorded in cluster III (303.98) and the minimum cluster mean values for number of pods/plant was recorded in cluster II (87.40) with general mean (234.32). The maximum cluster mean values for pod yield/plant (g) was recorded in cluster III (218.46 g) and the minimum cluster mean values was recorded in cluster II (98.93 g) with general mean $(177.29 \mathrm{~g})$. These results are similar with the finding of Muthuselvi et al., (2013) and Rai et 
al., (2013). The maximum cluster mean values for pod yield/hectare (q) was recorded in cluster III (95.55q) and the minimum cluster mean values was recorded in cluster II $(64.25$ q) with general mean $(82.13 q)$. The maximum cluster mean values for 10 dry pod weight $(\mathrm{g})$ was recorded in cluster III $(8.62 \mathrm{~g})$ and the minimum cluster mean values was recorded in cluster IV (5.72 g) with general mean $(6.87 \mathrm{~g})$. The maximum cluster mean values for number of seeds/pod was recorded in cluster II (8.87) and the minimum cluster mean values was recorded in cluster IV (6.10) with general mean (7.15). These results are similar with the finding of Muthuselvi et al., (2013) and Rai et al., (2013). The maximum cluster mean values for 100 seed weight $(\mathrm{g})$ was recorded in cluster II (4.80 g) and the minimum cluster mean values was recorded in cluster IV (3.15 g) with general mean (3.94 g). These results are similar with the finding of Girish et al., (2012) and Muthuselvi et al., (2013).

Table.1 Different genotypes of cluster bean collected from different states of India

\begin{tabular}{|c|c|c|c|}
\hline $\begin{array}{c}\text { S. } \\
\text { No. }\end{array}$ & Genotypes & $\begin{array}{c}\text { No. of } \\
\text { genotypes }\end{array}$ & Source of Genotypes \\
\hline 1. & $\begin{array}{l}\text { IC- } 13496, \text { IC-11388, } \\
\text { IC- } 40021, \text { IC-10345 }\end{array}$ & 4 & $\begin{array}{l}\text { University of Agriculture } \\
\text { Sciences(GKVK) Bangalore }\end{array}$ \\
\hline 2. & $\begin{array}{l}\text { Rajandgaon local }-1 \text {, } \\
\text { Rajandgaon local }-2, \mathrm{~S}- \\
77 \text {, Sarit saimaya }\end{array}$ & 4 & Local Genotype from Chhattisgarh \\
\hline 3. & $\begin{array}{l}\text { Sukoamal, Sarada, } \\
\text { Sona, Ankur rani }\end{array}$ & 4 & Local Genotype from Allahabad (U.P.) \\
\hline 4. & $\begin{array}{l}\text { RGC-1047, RGC-1025, } \\
\text { RGC-986 }\end{array}$ & 3 & RARI Durgapura Jaipur (Raj.) \\
\hline
\end{tabular}

Table.2 Distribution of 15 cluster bean genotypes into different clusters

\begin{tabular}{rccl}
\hline S. no. & $\begin{array}{l}\text { Cluster } \\
\text { numbers }\end{array}$ & $\begin{array}{l}\text { Number } \\
\text { genotypes }\end{array}$ & Genotypes included \\
\hline $\mathbf{1}$ & I & 5 & RGC-1047, Sarda, Sona, IC-13496, RGC-986 \\
$\mathbf{2}$ & II & 6 & $\begin{array}{l}\text { Rajandgaon Local-2, Rajnandgaon Local-1, Ankur } \\
\text { Rani, Sarit Saimaya, S-77, Sukomal }\end{array}$ \\
$\mathbf{3}$ & III & 4 & $\begin{array}{l}\text { IC- 10345, IC- 11388, IC- 40021 } \\
\mathbf{4}\end{array}$ \\
\hline
\end{tabular}

Table.3 Intra (diagonal) and inter cluster average distances $\left(\mathrm{D}^{2}\right)$ for different quantitative characters in cluster bean

\begin{tabular}{ccccc}
\hline Clusters & I & II & III & IV \\
\hline I & 1206.466 & 3562.381 & 5676.066 & 2823.086 \\
II & & 0 & 13811.78 & 8357.305 \\
III & & & 1049.48 & 2561.462 \\
\hline
\end{tabular}


Table.4 Cluster mean values of 4 clusters for different quantitative characters in cluster bean

\begin{tabular}{lccccc}
\hline \multicolumn{1}{c}{ Charters } & I & II & III & IV & Mean \\
\cline { 1 - 5 } Days to 1st flowering & & & & & \\
\hline Days to 50\% flowering & 33.95 & 34.00 & 37.93 & 35.66 & 35.51 \\
Plant height (cm) 45 Days & 36.28 & 36.00 & 40.53 & 37.83 & 37.88 \\
Plant height (cm) 90 Days & 37.87 & 28.00 & 53.29 & 43.16 & 43.06 \\
Branches/plant 45 Days & 94.65 & 100.20 & 115.21 & 84.23 & 100.48 \\
Branches/plant 90 Days & 5.41 & 7.66 & 3.08 & 6.36 & 4.91 \\
Days to 1st pod picking & 10.29 & 14.80 & 6.55 & 12.96 & 9.70 \\
10 fresh pod weight (g) & 49.95 & 51.66 & 52.00 & 53.16 & 51.17 \\
Pod length (cm) & 14.88 & 21.81 & 25.20 & 10.30 & 18.17 \\
Pod width (cm) & 8.84 & 14.36 & 14.48 & 7.12 & 10.86 \\
Number of clusters/plant & 0.81 & 0.94 & 0.87 & 0.76 & 0.83 \\
Number of pods/cluster & 49.83 & 36.00 & 60.00 & 68.96 & 54.85 \\
Number of pods/plant & 8.21 & 7.00 & 9.46 & 9.63 & 8.73 \\
Pod yield/plant (g) & 189.49 & 87.40 & 303.98 & 290.50 & 234.32 \\
Pod yield hectare (q) & 158.08 & 98.93 & 218.46 & 180.80 & 177.29 \\
10 dry pod weight (g) & 76.96 & 64.25 & 95.55 & 75.62 & 82.13 \\
Number of seeds/Pod & 6.08 & 6.00 & 8.62 & 5.72 & 6.87 \\
100 seed weight (g) & 6.94 & 8.87 & 7.52 & 6.10 & 7.15 \\
Seed yield/plant (g) & 4.23 & 4.80 & 3.68 & 3.15 & 3.94 \\
Seed yield/ha. (q) & 20.94 & 11.82 & 16.77 & 22.02 & 19.08 \\
\hline
\end{tabular}


Table.5 Percent contribution of different characters of the total diversity in cluster bean genotypes

\begin{tabular}{clrr}
\hline S. No. & \multicolumn{1}{c}{ Characters } & Time Ranked 1st & Contribution \% \\
\hline 1 & Days to 1st Flowering & 0.000 & 0.01 \\
2 & Days to 50\% Flowering & 0.000 & 0.01 \\
3 & Plant Height (cm) 45 Days & 0.000 & 0.01 \\
4 & Plant Height (cm) 90 Days & 1.000 & 0.95 \\
5 & Branches/ Plant 45 Days & 0.000 & 0.01 \\
6 & Branches/ Plant 90 Days & 0.000 & 0.01 \\
7 & Days to 1st Pod Picking & 0.000 & 0.01 \\
8 & 10 Fresh Pod Weight (g) & 0.000 & 0.01 \\
9 & Pod Length (cm) & 0.000 & 0.01 \\
10 & Pod Width (cm) & 0.000 & 0.01 \\
11 & Number of fruit clusters/plant & 0.000 & 0.01 \\
12 & Number of pods/ cluster & 0.000 & 0.01 \\
13 & Number of pods/plant & 22.000 & 20.95 \\
14 & Pod yield/plant (g) & 45.000 & 42.86 \\
15 & Pod yield/ hectare (q) & 14.000 & 13.33 \\
16 & 10 Dry Pod weight (g) & 5.000 & 4.76 \\
17 & Number of seeds/ pod & 9.000 & 8.57 \\
18 & 100 Seed weight (g) & 1.000 & 0.95 \\
19 & Seed yield/plant (g) & 2.000 & 1.90 \\
20 & Seed yield/ha. (q) & 6.000 & 5.71 \\
\hline
\end{tabular}

Fig.1 Distribution of 15 cluster bean genotypes into different clusters (Tocher Method)

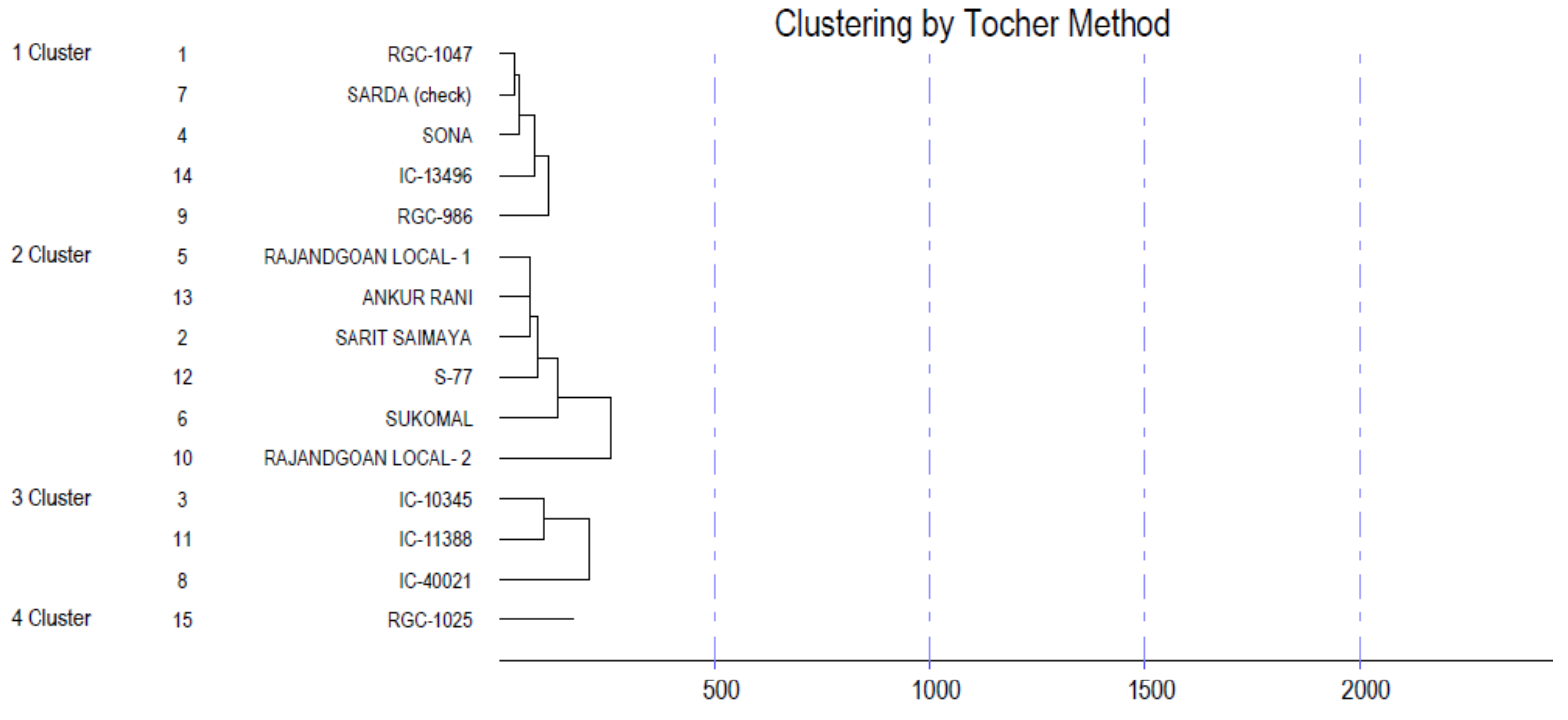


Fig.2

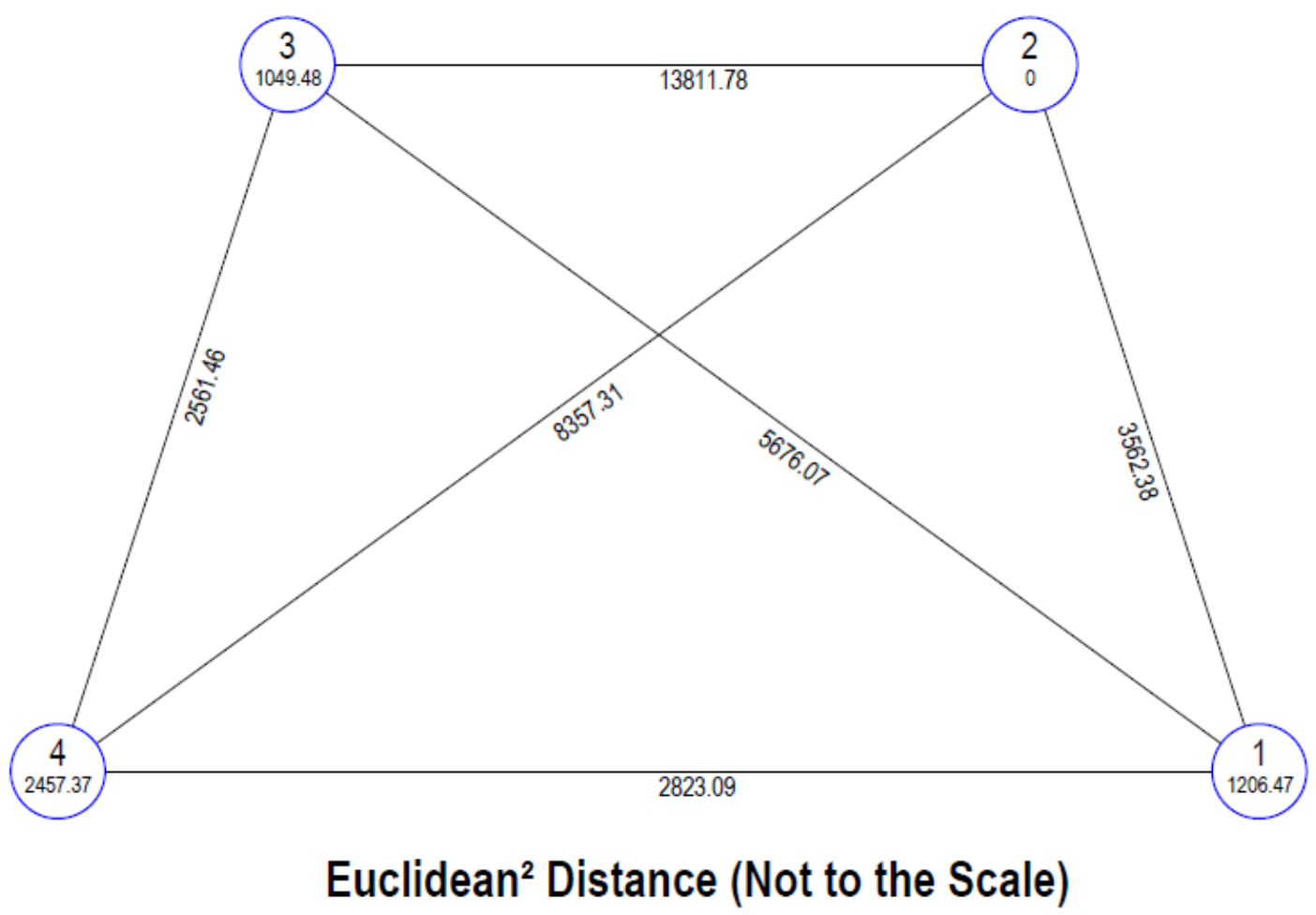

Fig.3 Ward's minimum variance dendrogram

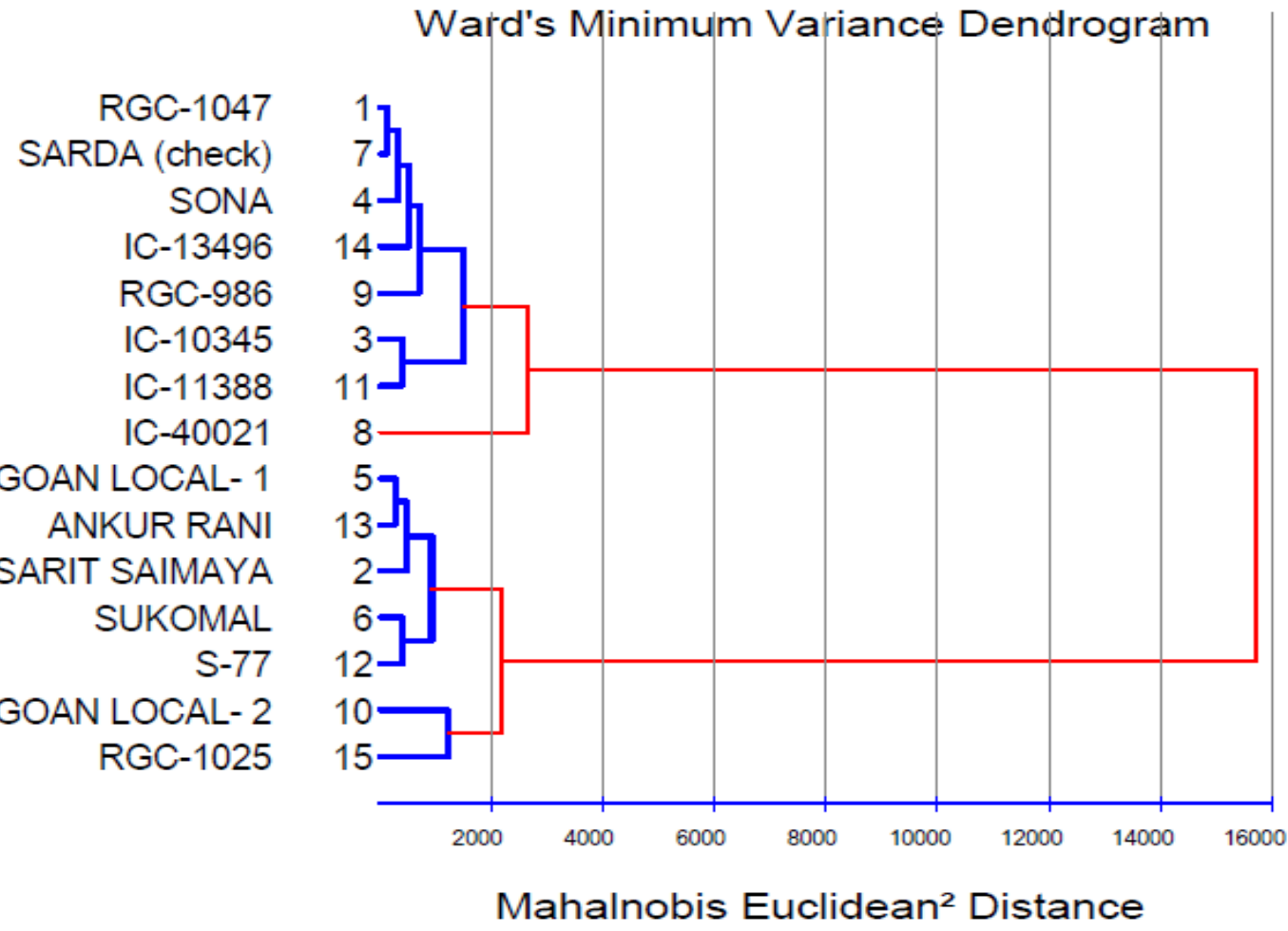


Fig.4 Percent contribution of different characters of the total diversity in cluster bean genotypes

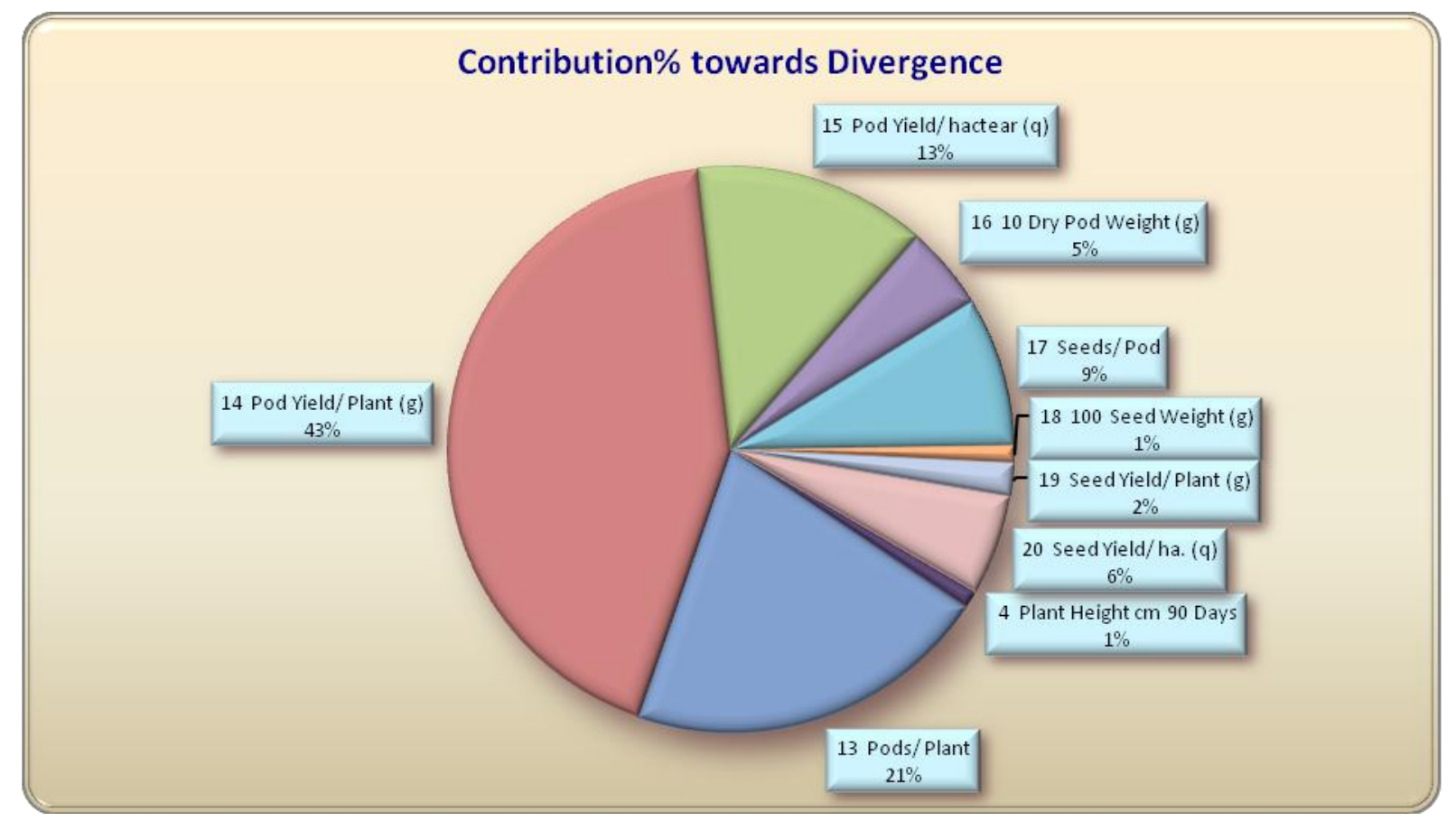

The maximum cluster mean for seed yield/plant $(\mathrm{g})$ was recorded in cluster IV $(37.02 \mathrm{~g})$ and the minimum cluster mean values was recorded in cluster II $(20.40 \mathrm{~g})$ with general mean $(31.84 \mathrm{~g})$. These results are similar with the finding of Muthuselvi et al., (2013). The maximum cluster mean for seed yield/ha (q) was recorded in cluster IV (22.02 q) and the minimum cluster mean values was recorded in cluster II (11.82 q) with general mean (19.08 q) (Table 4).

The characters like pod yield per plant $(\mathrm{g})$ contributed to $(42.86 \%)$ followed by pods/plant $(20.95 \%)$, pod yield/hectare (q) $(13.33 \%)$, seeds/pod $(8.57 \%)$, seed yield/ha. (q) $(5.71 \%), 10$ dry pod weight (g) (4.76\%), seed yield/plant (g) (1.90\%), 100 seed weight (g) and plant height $\mathrm{cm} 90$ days (0.95) and plant height $\mathrm{cm} 45$ days, branches/ plant 45 days, branches/ plant 90 days, days to taken $1^{\text {st }}$ flowering, days to $50 \%$ flowering, days to 1st pod picking, 10 fresh pod weight $(\mathrm{g})$, pod length $(\mathrm{cm})$, pod width $(\mathrm{cm})$, fruit clusters/ plant and pods/cluster contributed $(0.01 \%)$ of the total divergence in the genotypes (Table 5 and Fig. 4).

\section{Acknowledgement}

Authors are Sincerely Thankful to Dr. Vijay Bahadur Associate Prof., Department of Horticulture Naini agricultural institute SHUATS Allahabad (U.P). And Thanks to my friends Radhelal Dewangan, Ramesh, Shatis Xaxa, Mithlesh Gupta.

\section{References}

Girish, M.H., Gasti, V.D., Mastinoli, A.B., Thammaiah, N., Shantappa, T., Mulge, R., and kerutagi, M. 2012. Genetic divergence studies in cluster bean genotypes (Cyamopsis tetragonoloba (L.) Taub.) Karnataka J. Agri. Sci., 25(2): 245-247.

Kumar, D. and Singh, N.B. 2002. Guar in India. Scientific publishers (India) 
Jodhpur, Rajasthan, India.

Kumar, V., Ram, R.B. and Yadav, R.K. 2014. Genetic diversity in cluster bean [Cyamopsis tetragonoloba (L.) Taub.]. J. Sci. Tech., 7(8): 1144-1148.

Mahalanobis, P.C. 1928. On the generalised distance in statistics. Proceedings of the National Academy of Sci., 19: 201-208.

Muthuselvi, R. and Shanthi, A. 2013. Genetic diversity in cluster bean [Cyamopsis tetragonoloba (1.) taub]. The Asian J. Horticulture, Volume 8, Issue 2: 592595.

Pathak, R., Singh, M. and Henry, A. 2009. Genetic divergence in cluster bean
[Cyamopsis tetragonoloba (L.) Taub.] for seed yield and gum content under rainfed conditions. Indian J. Agric., Sci., 79(7): 559-561.

Rai, S. and Dharmatti, P.R. 2013. Genetic divergence studies in cluster bean (Cyamopsis tetragonoloba (L.) Taub.). Global J. Science Frontier Res. Agri. Vet., Volume 13, Issue 5.

Rao, C. R. (1952). Advance Statistical Methods in Biometrics Research. Hofaer Pub. Darion. pp. 371-378.

Vahrehvah. com. 2012. Redefining Indian food article, Cluster bean.

\section{How to cite this article:}

Praveen Choyal, Vijay Bahadur, Radhelal Dewangan, Ramesh, Shatis Xaxa and Mithlesh Gupta. 2017. Genetic Divergence Studies in Cluster Bean [Cyamopsis tetragonoloba (L.) Taub]. Int.J.Curr.Microbiol.App.Sci. 6(8): 1099-1107. doi: https://doi.org/10.20546/ijcmas.2017.608.136 